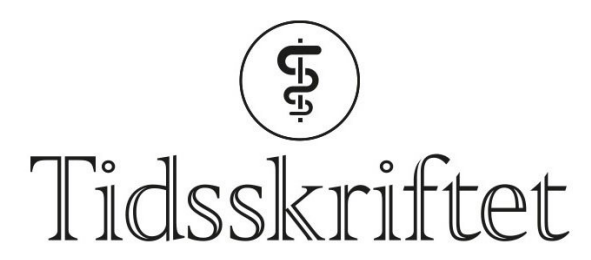

DEN NORSKE LEGEFORENING

\title{
Indikasjonsstillingen ved trombektomi
}

KOMMENTAR

\section{ANNE HEGE AAMODT}

E-post:a.h.aamodt@medisin.uio.no Anne Hege Aamodt er overlege ved Oslo universitetssykehus. Ingen oppgitte interessekonflikter.

\section{MARTIN KURZ}

Martin Kurz er seksjonsoverlege ved Stavanger universitetssykehus. Ingen oppgitte interessekonflikter.

\section{EVA A. JACOBSEN}

Eva A. Jacobsen er overlege er Oslo universitetssykehus og Universitetssykehuset i Nord-Norge, Tromsø.

Ingen oppgitte interessekonflikter.

\section{JON ANDRÉ TOTLAND}

Jon André Totland er overlege ved Universitetssykehuset i Nord-Norge, Tromsø. Ingen oppgitte interessekonflikter.

\section{OLE MORTEN RøNNING}

Ole Morten Rønning er seksjonsoverlege ved Akershus universitetssykehus. Ingen oppgitte interessekonflikter.

\section{LARS THOMASSEN}

Lars Thomassen er seksjonsoverlege ved Haukeland universitetssykehus. Ingen oppgitte interessekonflikter.

\section{CHRISTIAN G. LUND}

Christian G. Lund er overlege ved Oslo universitetssykehus. Ingen oppgitte interessekonflikter.

\section{HALVOR NAESS}

Halvor Næss er overlege ved Haukeland universitetssykehus. Ingen oppgitte interessekonflikter.

Vi vil takke for en fin kasuistikk som til fulle viser hvilket potensiale mekanisk rekanalisering (trombektomi) har ved cerebral storarterieokklusjon (1). Antall som må behandles for at én pasient skal komme gjennom et hjerneinfarkt med mindre grad av funksjonshemming (Number Needed to Treat, NNT), er 2,6. I Norge gjennomføres 
trombektomi per dags dato ved fem sykehus, og to nye sykehus skal starte med trombektomi fra neste år.

De fem store randomiserte trombektomi-studiene inkluderte hovedsakelig pasienter med større nevrologiske utfall. De fleste studiene hadde NIHSS-skår på minst 6 som nedre grense mens MR CLEAN-studien inkluderte pasienter med NIHSS-skår på minst 2 (2). Etter publiseringen av disse studiene er det blitt rutine å trombektomere pasienter også med lettere utfall. I metaanalysene hadde 581 pasienter NIHSS-skår $<8$ og 413 pasienter NIHSSskår $\leq 5$. De som ble behandlet med trombektomi, hadde signifikant bedre funksjonsnivå etter 3 måneder sammenliknet med dem som kun fikk medisinsk behandling $(3,4)$.

Ved St. Olavs hospital synes man å ha en meget konservativ utvelgelse av pasienter for trombektomi. Forfatterne skriver at behandlingen vanligvis ikke gjøres ved NIHSS-skår $<10$. Vi mener i overenstemmelse med publiserte metaanalyser at en slik høy grense for intervensjon gjør at endel pasienter går glipp av svært viktig akuttbehandling. Målet med trombektomi er å begrense skadevolumet i hjernen, ikke å reperfundere et hjernevolum som allerede er nekrotisk. Ved de andre trombektomi-sentrene i Norge vektlegges derfor CT/MR penumbra-vurdering, kollateralsirkulasjon og eventuelt diffusjonsfunn på MR sterkere enn selve NIHSS-skåren når indikasjonen for trombektomi stilles. I OUS-materialet fra 2017 hadde 39 av totalt 120 pasienter $(32,5 \%)$ NIHSS-skår < 10 på indikasjonstidspunktet (abstrakt presentert på Nevrodagene 2018 ved B. Enriques og medforfattere). Disse hadde klinisk og radiologisk et stort truet penumbravolum. Ved å bruke høy NIHSS-skår som indikasjon og ikke en individuell fysiologisk tilnærming vil trolig for få pasienter bli behandlet og det samlete resultatet etter trombektomi bli vesentlig dårligere enn det kunne ha vært.

\section{LITTERATUR:}

1. Manstad-Hulaas F, Herje M. Cerebral trombe uten sekvele. Tidsskr Nor Legeforen 2018; 138: doi: 10.4045/tidsskr.18.0050. [PubMed][CrossRef]

2. MR CLEAN Investigators. A randomized trial of intraarterial treatment for acute ischemic stroke. N Engl J Med 2015; 372: 11 - 20. [PubMed][CrossRef]

3. Xiong Y-J, Gong J-M, Zhang Y-C et al. Endovascular thrombectomy versus medical treatment for large vessel occlusion stroke with mild symptoms: A meta-analysis. PLoS One 2018; 13: e0203066.

[PubMed][CrossRef]

4. Griessenauer CJ, Medin C, Maingard J et al. Endovascular Mechanical Thrombectomy in Large-Vessel Occlusion Ischemic Stroke Presenting with Low National Institutes of Health Stroke Scale: Systematic Review and Meta-Analysis. World Neurosurg 2018; 110: 263 - 9. [PubMed][CrossRef]

Publisert:30. oktober 2018. Tidsskr Nor Legeforen. DOI: 10.4045/tidsskr.18.0771

(C) Tidsskrift for Den norske legeforening 2020. Lastet ned fra tidsskriftet.no 